\title{
Growth promoters in humans
}

\author{
BY H. J. G. BURNS* \\ University Department of Surgery, Royal Infirmary, Glasgow G4 OSF
}

\begin{abstract}
The maintenance and enhancement of body composition is an energy-dependent process and is impossible without an adequate supply of energy and protein. In certain circumstances, alteration of the normal pattern of protein deposition and metabolism may be considered necessary. Drugs have been used with some success in attaining this end in three distinct clinical areas. First, they are proving effective in the treatment of short-statured children, second, a variety of strategies have been used in an attempt to prevent loss of lean body mass in traumatized and septic patients, and finally and most controversially, the anabolic influences of a number of hormones have been used by sportsmen and women in a bid to improve athletic performance.
\end{abstract}

\section{SHORT STATURE}

The identification of the short-statured child has been made relatively easy with the widespread use of centile charts giving standards for height and weight for British children from birth to maturity (Tanner et al. 1966). Deciding the cause of an abnormally slow linear growth rate or a falling off of growth from previous levels is much more complex. Most short children have no obvious physical problem and their height may be due to familial or socio-economic factors (Parkin, 1976). Malnutrition, chronic inflammatory diseases, renal insufficiency and congenital cyanotic cardiac abnormalities account for many of the more obvious causes of growth retardation. Hypothyroidism delays skeletal maturation and results in severe dwarfism if untreated. In each case, the slow growth is improved by correction of the underlying defect. These conditions require early diagnosis and treatment for normal height to be attained.

When growth is interrupted by a period of starvation or illness, the child shows the phenomenon of catch-up growth, which might be two or three times the usual rate, until he has once again reached the height he would have attained but for the illness. If growth is prevented for too long or at too early an age, the child may never catch up. Dahlman \& Petersen (1977) studied the effect of malnutrition on final body size in German children and concluded that if the starvation occurred after the fourth year, then its effects were much less than if it occurred earlier. It seems important, therefore, to detect slow growth as early as possible and child surveillance in Child Health clinics has been an important public health measure.

Where careful examination and investigation has shown growth failure as a result of growth hormone $(\mathrm{GH})$ deficiency, this can be successfully treated in most cases by replacement therapy with synthetic hormone. There is also some evidence that short children with no obvious pathology may respond to the use of GH.

The use of GH extracted from human pituitary to treat short stature was first reported by Raben (1958) and a large study reported that its use would produce an average growth

* Present address: Department of Public Health, University of Glasgow, 2 Lilybank Gardens, Glasgow G12 8RZ. 
response of $89 \mathrm{~mm}$ in the first year of use (Milner et al. 1979). The response was better in younger patients and the growth rate decreased as treatment continued. It was clear also that significant benefit was unlikely if $\mathrm{GH}$ was administered after epiphyseal fusion. Powell-Jackson et al. (1985) reported the death from Creutzfeld-Jacob disease of a 22 year old who had been treated in childhood with pituitary-derived GH. It is likely that this degenerative disease of the central nervous system was caused by transmission of the infective agent in the $\mathrm{GH}$ which had probably been prepared from the brains of affected individuals. A few months after the pituitary-derived GH was withdrawn, American regulatory authorities approved the use of $\mathrm{GH}$ prepared using recombinant DNA techniques. This substance differs from native human $\mathrm{GH}$ by having an extra amino acid (methionine). It is an effective growth promoter in children and the only question over its use so far appears to be the fact that about $30 \%$ of children develop antibodies to $\mathrm{GH}$ and a smaller proportion develop antibodies to the organism used in its production, $E$. coli. These antibodies do not appear to cause problems and do not affect growth rates in treated children (Kaplan et al. 1986).

Before starting treatment, it is axiomatic that the diagnosis of $\mathrm{GH}$ deficiency must be confirmed and that other conditions which may cause $\mathrm{GH}$ deficiency and which are potentially curable are excluded. Such conditions are mainly tumours of the central nervous system such as craniopharyngiomas. It is outside the scope of the present article to discuss the diagnosis further but Brook et al. (1986) review this in some detail. Conditions such as hypothyroidism and nutritional deficiency must be detected and corrected before stimulation of growth. For monitoring purposes, pretreatment growth velocity should be measured over the 6 months preceding treatment. Since it is a large protein molecule, methionyl-GH must be given parenterally and children or parents are taught to administer it on a once daily basis by subcutaneous injection. Frequent follow-up at 3-month intervals is necessary to assess growth response and to encourage compliance. Throughout this period attention must be paid to the possibility that $\mathrm{GH}$-deficient patients may be deficient in other pituitary hormones as well and the growth spurt may be prevented by unsuspected trophic hormone deficiency resulting in thyroid or adrenal hypofunction or diabetes insipidus.

Short children with apparently normal stimulated levels of $\mathrm{GH}$ may have a reduced 24 h secretion (Hindmarsh et al. 1987) or may have biologically inactive GH which reacts immunologically to give misleadingly normal tests (Kowarski et al. 1978). Several groups have shown that short, non-GH-deficient children will respond with increased growth velocity to treatment with GH (Van Vliet et al. 1983; Spiliotis et al. 1984; Hindmarsh \& Brook, 1987). In addition, short children with chromosomal abnormalities such as Turner's syndrome appear to benefit from treatment (Raiti, 1986).

Other possibilities exist for treatment of short stature. Some children fail to respond to GH therapy, possibly because of the presence of high levels of anti-GH antibody. An alternative strategy in these individuals might be the use of somatomedins. The anabolic effects of $\mathrm{GH}$ may be largely mediated by these substances and once sufficient quantities of peptides such as somatomedin- $\mathrm{C}$ are available clinical trials of this approach in the GH-resistant children will be possible. Stimulation of $\mathrm{GH}$ release from the pituitary by dopaminergic agents such as bromocriptine (Huseman \& Hossing, 1984) or by adrenergic pathways using clonidine (Pintor et al. 1985) have been successful within the context of controlled trials. At present this strategy offers no clear benefit over $\mathrm{GH}$ treatment. 


\section{GROWTH PROMOTION IN STRESSED PATIENTS}

Cuthbertson (1930) was the first investigator to describe a negative nitrogen balance after injury. The development of sophisticated intensive care services now permits prolonged survival of patients with severe $\mathrm{N}$ loss. The main source of $\mathrm{N}$ in these patients is skeletal muscle and a continued inflammatory response may result in a major alteration in body composition (Wilmore et al. 1971). This response appears similar to that seen in cancer patients where $80 \%$ of skeletal muscle and $60 \%$ of fat stores can be lost in cases of advanced disease (Preston et al. 1987).

A variety of endocrine manoeuvres have been used in an attempt to reduce protein loss in these patients. Wilmore et al. (1974) suggested the use of GH and studies showed an improved $\mathrm{N}$ balance in burned patients. More recently, improved $\mathrm{N}$ balance and improved protein synthesis have been demonstrated in elective surgical patients receiving GH (Ward et al. 1987).

Anabolic steroids have been of interest since Johnston \& Chenneour (1963) observed a significant improvement in $\mathrm{N}$ balance in patients undergoing elective surgery and who received a single dose of anabolic steroid. Several other workers have confirmed this observation (Blamey et al. 1984; Hansell et al. 1987). In a study which attempted to assess the effect of steroids on body composition, no significant effect was found (Yule et al. 1981).

An ingenious experiment showed that glucagon release from the pancreas was implicated in protein loss in ill subjects. Shaw \& Wolfe (1988) infused somatostatin into patients while maintaining plasma glucose with a simultaneous insulin infusion. They demonstrated a $14 \%$ reduction in the net rate of protein breakdown.

One of the most interesting possibilities for endocrine manipulation has followed the recognition of the importance of adrenaline as a mediator of the stress response (Bessey et al. 1984). In rat skeletal muscle, adrenaline has been shown to inhibit the release of free amino acids and, hence, prevent protein loss (Garber et al. 1976). A reduction in catecholamine excretion in surgical patients can be obtained by blocking neural pathways using spinal or epidural anaesthesia (Pflug \& Halter, 1981). A highly significant improvement in $\mathrm{N}$ balance has been observed in patients undergoing pelvic surgery while receiving analgaesia by continuous infusion of the local anaesthetic bupivacaine into the epidural space (Brandt et al. 1978) and an 11\% reduction in protein turnover has been reported in patients anaesthetized in a similar fashion by Shaw et al. (1987).

Other attempts to inhibit adrenal function have relied on the use of alpha- or beta-adrenergic blockade. Modification of several aspects of the metabolic response to injury have been reported using phentolamine (Allison et al. 1969), and propranolol (Tsuji et al. 1980). These substances appear to effect energy homeostasis rather than protein metabolism. Most interesting effects in this area are shown by the beta-agonist, clenbuterol. It has been demonstrated in animal studies that clenbuterol can increase muscle mass and decrease body fat (Emery et al. 1984). How it achieves this effect is uncertain since its growth-promoting action is not inhibited by beta-blockade (Reeds et al. 1988). No published information is available as to the potential clinical benefits of this drug but it appears to have come to the notice of sportsmen and body-builders, and anecdotal evidence suggests that it may have a significant effect in healthy human subjects. Asoh et al. (1987) reported that patients receiving indomethacin following surgery had an $18 \%$ reduction in post-operative $N$ excretion. Treated patients also had a reduction in pyrexia. The possibility that non-steroidal anti-inflammatory drugs could 
reduce protcin loss was suggested by Baracos et al. (1983). The effects of these agents on muscle protein synthesis and degradation are complex and are probably dose related (Reeds \& Palmer, 1986). A more important reason for caution is the observation that the stimulatory effect of indomethacin on synthesis may occur only if the drug is present at the onset of injury (Palmer et al. 1986). This clearly limits their clinical usefulness.

The discussion has centred round the effectiveness of various drugs in reducing $\mathrm{N}$ excretion and protein turnover. Improvement in a biochemical measurement is not relevant unless clinical benefit is also seen. For example, a $15-20 \%$ reduction in cumulative $\mathrm{N}$ excretion over the $3 \mathrm{~d}$ following gastrectomy in the study reported by Asoh et al. (1987) was equivalent to approximately $60 \mathrm{~g} \mathrm{~N}$ or $405 \mathrm{~g}$ protein. The study patients weighed about $50 \mathrm{~kg}$ and, therefore, the 'spared' protein represented less than $1 \%$ of body-weight. Such calculations are, of course, dependent on so many assumptions as to be quite inaccurate, but this example serves to put the benefits to be obtained by the use of these drugs in some perspective. So far no studies have shown a clear improvement in terms of reduced morbidity or mortality in patients treated in this fashion. The likelihood is that any benefit to be obtained from preservation of muscle will be obvious in improved function or shortened convalescence. Such endpoints are often difficult to demonstrate. As yet, no convincing evidence of benefit has been shown in clinical trials. No definite recommendation as to their use can be made in stressed patients and provision of nutrients, either enterally or parenterally, in quantities sufficient to meet daily requirements, remains the most important aid to maintenance of body composition in complicated surgical patients (Burns, 1988).

\section{GROWTH PROMOTERS IN SPORT}

Great attention has been paid to the problem of drug use in sport since the disqualification of the winner of the $100 \mathrm{~m}$ sprint in the Seoul Olympics. Stanozolol, the drug taken in this case, is an anabolic steroid which has been used in clinical practice as a treatment for post-phlebitic syndrome. The subsequent inquiry into the affair held by the Canadian sports authorities found that the use of stanozolol was widespread among sprinters. This impression was supported by Dr Robert Voy, chief medical officer to the US Olympic Committee who reported that six of 200 athletes in the US Olympic trials were found to have been taking these drugs at the time of the trial. Dr Voy commented that the only sports in his experience to be drug free were women's hockey and figure skating (Cowart, 1988).

Anecdotal evidence suggests that athletes using growth promoters are becoming more sophisticated in their choice of drugs, perhaps because of the side effects of anabolic steroids. GH, testosterone and human chorionic gonadotrophin are now being taken by athletes in an attempt to evade detection methods (Malcolm Brown. personal communication). The effects of these drugs on performance have not been published for obvious reasons. An attempt to promote the growth of a specific body compartment is exemplified by the practice of 'blood doping' in which endurance athletes are venesected of a unit of blood some weeks in advance of competition (Jones \& Tunstall Pedoe, 1989). It is re-transfused after their packed cell volume returns to normal. This results in an elevation in erythrocyte mass and oxygen-carrying capacity. It is obviously difficult to detect, although one Olympic medallist was disqualified because the blood he had re-transfused contained minute quantities of the anabolic steroid he had been taking 
some weeks previously when venesected. A more sophisticated approach to blood doping is inevitable now that human erythropoetin has become available!

\section{REFERENCES}

Allison, S. P., Tomlin, P. J. \& Chamberlain, M. J. (1969). Some effects of anaesthesia and surgery on carbohydrate and fat metabolism. British Journal of Anaesthesia 41, 588-593.

Asoh, T., Shirasaka, C., Uchida, I. \& Tsuji, H. (1987). Effects of indomethacin on endocrine responses and nitrogen loss after surgery. Annals of Surgery 206, 770-776.

Baracos, V., Rodemann, H. P., Dinarello, C. A. \& Goldberg, A. L. (1983). Stimulation of muscle protein degradation and prostaglandin E2 release by leukocytic pyrogen (interleukin 1). A mechanism for the increased degradation of muscle proteins during fever. New England Journal of Medicine 308, 553-558.

Bessey, P. Q. Watters. J. M.. Aoki, T. T. \& Wilmore, D. W. (1984). Combined hormone infusion simulates the metabolic response to injury. Annals of Surgery 200, 264-281.

Blamey, S. L., Garden, O. J., Shenkin. A. \& Carter, D. C. (1984). Modification of nitrogen balance following surgery with a preoperative anabolic steroid. Clinical Nutrition 2, 187-192.

Brandt, M. R., Fernandes, A., Mordhorst, R. \& Kehlet, H. (1978). Epidural analgesia improves postoperative nitrogen balance. British Medical Journal 1, 1106-1108.

Brook, C. G. D., Hindmarsh, P., Smith, P. \& Stanhope, R. (1986). Clinical features and investigation of growth hormone deficiency. Clinics in Endocrinology and Metabolism 15, 479-493.

Burns, H. J. G. (1988). Nutritional support in the perioperative period. British Medical Bulletin 44, 357-373.

Cowart, R. (1988). Issues of drugs and sports gain attention as Olympic Games open in South Korea. Journal of the American Medical Association 260, 1513-1518.

Cuthbertson, D. P. (1930). The disturbance of metabolism produced by bony or non-bony injury, with notes on certain abnormal conditions of bone. Biochemical Journal 24, 1244-1263.

Dahlman, N. \& Petersen, K. (1977). Influence of environmental conditions during infancy on final body stature. Paediatric Research 11, 695-700.

Emery, P. W., Rothwell, N. J., Stock, M. J. \& Winter, P. D. (1984). Chronic effects of beta adrenergic agonists on body composition and protein synthesis in the rat. Bioscience Reports 4, 83-89.

Garber, A. J., Karl, I. E. \& Kipnis. D. M. (1976). Alanine and glutamine synthesis and release from skeletal muscle: Beta-adrenergic inhibition of amino acid release. Journal of Biological Chemistry 251, 851-857.

Hansell, D. T., Davies, J. W. L., Shenkin, A., Garden, O. J., Burns, H. J. G. \& Carter, D. C. (1987). The effects of an anabolic steroid and aftidrofuryl on the metabolic response to surgery. Nutrition 3, 249-255.

Hindmarsh, P. \& Brook, C. G. D. (1987). Effect of growth hormone on short normal children. British Medical Journal 295, 573-597.

Hindmarsh, P., Smith, P. J., Brook, C. G. D. \& Mathews, D. R. (1987). The relationship between height velocity and growth hormone secretion in short prepubertal children. Clinical Endocrinology 27, 581-591.

Huseman, C. A. \& Hossing, J. M. (1984). Evidence of dopaminergic stimulation of growth velocity in some hypopituitary children. Journal of Clinical Endocrinology and Metabolism 58, 419-425.

Johnston, I. D. A. \& Chenneour, R. (1963). The effect of methandienone on the metabolic response to surgical operation. British Journal of Surgery 50, 924-928.

Jones, M. \& Tunstall Pedoe, D. S. (1989). Blood doping - a literature review. British Journal of Sports Medicine 23, 84-88.

Kaplan, S. L., Underwood, L. E., August, G. P., Bell, J. J., Blethen, S. T., Blizzard, R. M., Brown, D. R., Folcy, T. P., Hintz, R. L. \& Hopwood, N. J. (1986). Clinical studies with recombinant-DNA-derived methionyl human growth hormone in growth hormone deficient children. Lancet i, 697-700.

Kowarski, A. A., Schneider, J., Ben-Galim, E., Weldon, V. V. \& Daughaday, W. H. (1978). Growth failure with normal serum RIA-growth hormone and low somatomedin activity: somatomedin restoration and growth acceleration after cxogenous growth hormone. Journal of Clinical Endocrinology' and Metabolism 47, 461-464.

Milner, R. D., Russell-Fraser, T., Brook, C. G. D., Cotes, P., Farquar, J., Parkin, J., Preece, M., Snodgrass, G., Mason. A., Tanner, J. \& Vince, F. (1979). Experience with human growth hormone in Great Britain: the report of the MRC working party. Clinical Endocrinology 11, 15-38.

Palmer, R. M., Bain, P. A. \& Reeds, P. J. (1986). Time dependent effect of indomethacin on the stimulation of protein synthesis in isolated rabbit muscle by insulin. Bioscience Reports 6, 485-491.

Parkin, J. M. (1976). Short stature. British Medical Journal ii, 1139. 
Pflug. A. E. \& Halter, J. B. (1981). Effect of spinal anaesthesia on adrenergic tone and the neuroendocrine response to surgical stress in humans. Anaesthesiology 55, 120-126.

Pintor, C.. Cella. S. G.. Corda, R., Puggionni, R., Locatteli, V.. Loche. S. \& Muller, E. (1985). Clonidine accelerates growth in children with impaired growth hormone secretion. Lancet $\mathrm{i}, 1482-1485$.

Powell-Jackson. J., Weller, R. O., Kennedy, P., Preece, N. A., Whitcombe, E. M. \& Newsom Davis, J. (1985). Creutzfeld-Jacob disease after administration of human growth hormone. Lancet ii. 244-246.

Preston, T., Fearon, K., Robertson, I., East, B. \& Calman. K. (1987). Tissue loss during severe wasting in lung cancer patients. In In Vivo Body Composition Studies, pp. $60-69$ [K. J. Ellis, S. Yasumura and W. D. Morgan, editors]. London: Institute of Physical Sciences in Mcdicine.

Raben. M. S. (1958). The treatment of a pituitary dwarf with human growth hormone. Journal of Clinical Endocrinology and Metabolism 18, 901-903.

Raiti, S. (1986). Growth-stimulating effects of human growth therapy in Turner's syndrome: preliminary report. In Human Growth Hormone, pp. 109-113 [S. Raiti and R. A. Tolman, editors]. New York: Plenum Medica.

Reeds, P. J., Hay, S. M.. Dorward, P. M. \& Palmer, R. M. (1988). The effect of beta agonists and antagonists on muscle growth and body composition of young rats. Comparative Biochemistry and Physiology $89 \mathrm{C}$, $337-341$.

Reeds, P. J. \& Palmer, R. M. (1986). The role of prostaglandins in the control of muscle protein turnover. In Control and Manipulation of Animal Growth, pp. 161-185 [P. J. Buttery, N. B. Haynes and D. B. Lindsay, editors]. London: Butterworths.

Shaw, J. H. F., Galler. L., Holdaway, I. M. \& Holdaway, C. M. (1987). The effect of exira dural blockade upon glucose and urea kinetics in surgical paticnts. Surgery, Gynecology and Obstetrics 165, 260-266

Shaw. J. H. F. \& Wolfe, R. R. (1988). Metabolic intervention in surgical patients. An assessment of the effect of somatostatin, ranitidine. naloxone, diclophenac, dipyrimadole or salbutamol on energy and protein kinetics in surgical patients using stable and radio-isotopes. Annals of Surgery 207, 274-282.

Spiliotis, B., August, G., Hung, W., Sonis, W., Mendelson. W. \& Bercu, B. (1984). Growth hormone neurosecretory dysfunction. Joumal of the American Medical Association 251, 2223-2230).

Tanner. J. M., Whitehouse, R. H. \& Takaishi, M. (1966). Standard from birth to maturity for height, weight, height velocity and weight velocity: British children. 1965 Part II. Archives of Diseases of Cinildren 41, 613-615.

Tsuji, H., Asoh. T., Shirasaka, C. \& Takenchi, Y. (1980). Inhibition of metabolic responses to surgery with beta adrenergic blockade. British Journal of Surgery 67, 503-505.

Van Vliet, G. V., Styne, D., Kaplan, S. \& Grumbach, M. (1983). Growth hormone treatment for short stature. New England Journal of Medicine 309, 1016-1022.

Ward, H. C., Halliday, D. \& Sim, A. J. W. (1987). Protein and energy metabolism with biosynthetic human growth hormone after gastrointestinal surgery. Annals of Surgery 206, 56-61.

Wilmore, D. W., Curreri, P. W., Spitzer, K. W. Spitzer, M. E. \& Pruitt, B. A. (1971). Supranormal dietary intake in thermally injured hypermetabolic patients. Surgery, Gynecology and Obstetrics 132, 881-886.

Wilmore, D. W. Moglan, J. A., Bristow, B. R., Mason, A. D. \& Pruitt, B. A. (1974). Anabolic effects of human growth hormone and high caloric feedings following thermal injury. Surgery. Gynecology and Obstetrics 138, 875-884.

Yule, A. G., Macfie, J. \& Hill, G. L. (1981). The effect of an anabolic steroid on body composition in patients receiving intravenous nutrition. Australian and New Zealand Journal of Surgery 51, 280-284. 